\title{
The Dethroning of DNA
}

\author{
*Diego López Alonso \\ Universidad de Almería, Spain
}

Submission: October 25, 2017; Published: October 30, 2017

*Corresponding author: Diego López Alonso, Universidad de Almería, Deparment of Biology and Geology, 04120 Almería, Spain, Email: dlopez@ual.es

\section{Introduction}

The discovery of epigenetic phenomena and its widespread influence on the ontogeny of every organism has led to a new appreciation of the developmental processes within evolutionary biology. Some "evo-devo" scholars even ask for a redefinition of current evolutionary theory to accommodate these new phenomena because, they argue, Neo-Darwinian theory is too gene-centered and new data challenges this view [1-3]. Putting aside the mischaracterization of the evolutionary theory made by, for instance, Lickliter and Honeycutt [1], which creates a straw-man theory for their convenience [4], the main point of contention is the relationship between genotype and phenotype. The view of evo-devo scholars can be summarized in these words: "The development of any individual organism is the consequence of a unique web of interactions among the genes it carries; the complex, multi determined molecular interactions within and across individual cells; and the nature and sequence of the physical, biological, and social environments through which it passes during development [1]".

This explanation, supposedly challenging current evolutionary theory can in fact be easily subscribed to by most evolutionary biologists without hesitation [5]. Actually, two evolutionary psychologists, John Too by and Leda Cosmides [6], as early as 1990, gave a quite similar explanation: “[...] The phenotype is the result of an interaction between genes and environment, and all aspects of the phenotype are equally codetermined by this interaction. Developmental programs (i.e. the regulatory processes that control development) are directed by the genes, but they require and depend upon an entire range of properties of the environment being reliably and stably present in order to successfully produce a healthy individual". Quite similar but not completely the same.

From the evo-devo stand point, the role of genes in the development of an organism is 'diluted' by a complex network of near-equally weighted factors whereas in current evolutionary theory, genes retain their central role. In the view of evodevo proponents, the metaphor of the genome as 'blueprint' is explicitly rejected. Here, it is expressed in a moderate way: "Caution should be taken when thinking of the genetic material as a 'blueprint' [...]. [...] gene action is an integral part of the system although not necessarily the source of organization in the system" [7]. In a cruder form: Genetic programs do not, however, determine individual development [1]

This supposition is expressed in many different ways: "All available data suggest that genomic deoxyribonucleic acid (DNA) is but one of many informational systems in the cell. [...] the proteins bound to loci are just as important in heredity as DNA itself" [8]. "Similarly, an organism is built and operates with the help of its genome; but the genome is only one element in a recursive process. [...] the meaning of a DNA sequence cannot be derived from the sequence itself. Thus the genome does not encode a coherent plan for a sequence of events" [9]. (Emphasis added.).

Hence, the informational role of the DNA/genome in the development of an organism is always discredited in favor of a 'republic' of near-equally weighted factors. In short, the development process is 'decapitated'; there is no 'King', no head, no direction, no hierarchy, no central control, and no genome playing a central role... As a corollary, this logic leads to the unavoidable and bizarre conclusion that the system is 'self-organizing', as expressed in the following quotations: "[...] the system might have self-organizing properties" [7]. "It is more helpful to understand developmental processes as ones of autopoiesis (literally self-creation), in which organisms, and perhaps especially humans, actively construct themselves out of the raw materials of their genes and environment" [10]. (Emphasis added.) The paroxysm is reached in book titles such as "The Art of the Genes: How Organisms Make Themselves".

If one follows this argument, developmental processes, by themselves, spontaneously concatenate a network of perfectly organized events. They need nothing at all, either a blueprint or any decision-like device to find the right path. Magically, the development itself always finds the right route amongst a huge array of different possibilities. A myriad of factors are involved 
in the process, self-ordinate in a causal network that ends in a perfectly developed phenotype... Well, a proposition such as this is absurd! A disorganized world can never spontaneously produce an organized world. The statements I have cited above can only be described as utter nonsense and they deserve to be rejected. I believe that such declarations cannot stand without being roundly refuted; yet, to my surprise, I have read no such refutations. This letter seeks to provide one.

First of all, it must be noted that the evo-devo viewpoint proposes the practical deletion of the Population Genetics base of current evolutionary theory, "the most powerfully predictive, broadly applicable and empirically validated component of evolutionary theory" [11]. They are proposing to eliminate the most tested and supported element of current evolutionary theory, and substitute it with a new unvalidated theoretical model.

The supporters of evo-devo also propose to demolish the central role played by the DNA/genome in the phenotype, particularly for human behavior; meanwhile, current research is producing a growing body of evidence highlighting the unmistakable, primal role played by genes in animal behavior [12-17], showing how certain single genes have major effects on behavior [18]. Additionally, the clever application of modern research tools is producing a detailed disentanglement of some complex behavioral mechanisms revealing the neural circuits, the molecules involved, and even the specific neurons that integrate them $[12,15,19,20]$. Finally, it is unquestionable that the existences of a number of human neurological diseases that are genetic in origin demonstrate the strong link between genes and the nervous system [21-23].

In contrast, evo-devo theory relies heavily on the inflated evolutionary significance of inherited epigenetic traits even though there is little evidence supporting the role of inherited epigenetic modification in adaptation [11]. Indeed, the transmission of epigenetic modification spans no than one or two generations $[24,25]$, thus throwing significant doubt on the evolutionary impact of these traits.

There is however no need to enter into a detailed discussion on a point-by-point basis because it is very easy to uncover the fatal flaw in the evo-devo accounts. We can put aside the complex intricacies of ontogenetic development and simply observe the end result, placing the former on a second tier of importance. We ought to pay more attention to the general overview and, in doing so, avoid the habitual problem of being 'unable to see the wood from the trees'. To reject this theory in the most robust fashion, it is enough simply to look at the most obvious fact - from a human zygote gestation results in a human baby despite the complex network of interactions that occur through its embryonic and fetal development. A human zygote does not produce a cow, nor a monkey, nor any other animal or plant, but a human baby. Always, without exception. Similarly, a fish zygote results in a fish, a reptile zygote in a reptile, and so on. How can the 'headless' process proposed by evo-devo supporters produce such consistent results? If there is no body plan, no blueprint, no instructions, no genes or anything similar, the fit of each and every ontogenetic developmental stage to its species-specific pattern has no explanation. The obvious point has been simply stated: "What would we as humans, or any animal, are without genes? Nothing; we wouldn't exist" [4].

The informative role that the genome plays easily explains the facts. The genome carries the appropriate information to build a human, (or a fish, or a reptile). The genome is the 'blueprint' for a specific organism; it contains the information required to drive the developmental process correctly up to the point where a new-born baby is formed. As emphasized by this most evident fact: "People can predict with great accuracy that members of their species will have two eyes and two ears; [...]" [4].

Both within and between its coded information, the genome regulates which genes to express and which to disconnect on receipt of specific signals (genetic and non-genetic; biological and non-biological) from the environment. The environment that surrounds the zygote/embryo/fetus is already specified in the genome. It is fully expected which signals and when they will activate. Ontogenetic development is coded in the genome because it is mostly constant, almost identical to the previous iteration. It has been encoded in the species' genome by evolution.

It should be noted that not all environmental factors are capable of acting as signals, because most are evolutionarily irrelevant; that is, they have not been chosen by natural selection as they have no impact on reproductive success. The genome is developmentally sensitive only to those environmental cues that have been evolutionarily selected: The environment of an animalin the sense of which features of the world it depends on or uses as inputs-is just as much the creation of the evolutionary process as the genes are" [6]. More recent evidence provides support for this statement: "[...] the physiological responses of neural populations to ethologically relevant stimuli [...]" [19].

In contrast to the process envisioned and described by evodevo scholars, which is supposedly variable from one individual to another, ontogenetic development occurs in a basically invariant environment, and the result is usually a healthy newborn baby. Moreover, if any anomaly occurs during the baby's development, it may show some phenotypic anomalies; never the less, the child will retain most of the species-specific traits making her/him recognizable as a human being. The blueprint olds the essential traits (whether for the body, the brain or for behavior, etc.) which characterizes the species and its innate human nature.

\section{References}

1. Lickliter R, Honeycutt H (2003) Developmental dynamics: Toward a biologically plausible Evolutionary Psychology. Psychol Bull 129(6): 819-835. 
2. Laubichler MD (2009) Evolutionary Developmental Biology offers a significant challenge to the Neo-Darwinian paradigm. In Ayala FJ, Arp R (eds), Contemporary Debates in Philosophy: Contemporary Debates in Philosophy of Biology. Wiley-Blackwell, Hoboken, USA, 199-212.

3. Laland K, Uller T, Feldman M, sterelny K, Muller GB, et al. (2014) Does evolutionary theory need a rethink? Yes, urgently. Nature 514: 161164

4. Krebs DL (2003) Fictions and facts about evolutionary approaches to human behavior: Comment on Lickliter and Honeycutt. Psychol Bull 129(6): 842-847.

5. Minelli A (2009) Evolutionary Developmental Biology does not offer a significant challenge to the Neo-Darwinian paradigm. In Ayala FJ, Arp R (eds), Contemporary Debates in Philosophy: Contemporary Debates in Philosophy of Biology. Wiley-Blackwell, Hoboken, US, 213-226.

6. Tooby J, Cosmides L (1990) On the universality of human nature and the uniqueness of the individual: the role of genetics and adaptation. J Pers 58: 17-67.

7. Goldsmith H (2005) Gene-to-behavior pathways. Encycl Life Sci 4.

8. Salthe SN, von Sternberg R (2009) Biological complexity: Beyond the genome. Encycl Life Sci 3.

9. Cohen IR, Atlan H, Efroni S (2009) Genetics as explanation: Limits to the Human Genome project. Encycl Life Sci 8.

10. Rose SP (2012) Genetics, reductionism and autopoiesis. Encycl Life Sci 3.

11. Wray GA, Hoekstra HE, Futuyma DJ, Richard E Lenski, Trudy FC Mackay, et al. (2014) Does evolutionary theory need a rethink? Nature 514(7521): 161-164.

12. Sokolowski MB (2001) Drosophila: Genetics meets behaviour. Nat Rev Genet 2(11): 879-890.

13. Kyriacou CP (2002) Single gene mutations in Drosophila: What can they tell us about the evolution of sexual behaviour? Genetica $116(2$ -

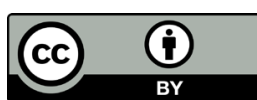

This work is licensed under Creative

Commons Attribution 4.0 License

DOI: $10.19080 /$ PBSIJ.2017.07.555712
3): 197-203.

14. Casey BJ, Glatt CE, Tottenham N, Soliman F, Bath K, et al. (2009) Brainderived neurotrophic factor as a model system for examining gene by environment interactions across development. Neuroscience 164: 108-120.

15. Sokolowski K, Corbin JG (2012) Wired for behaviors: From development to function of innate limbic system circuitry. Front Mol Neurosci 5: 55.

16. Bergersen LH, Bramham CR, Hugdahl K, Sander M, Storm Mathisen J (2013) The changing brain: Insights into the mechanisms of neural and behavioral adaptation to the environment. Neuroscience 247: 412 -422 .

17. Micevych PE, Meisel RL (2017) Integrating neural circuits controlling female sexual behavior. Front Syst Neurosci 11: 42

18. Takahashi JS, Shimomura K, Kumar V (2008) Searching for genes underlying behavior: Lessons from circadian rhythms. Science 322(5903): 909-912.

19. Manoli DS, Meissner GW, Baker BS (2006) Blueprints for behavior: Genetic specification of neural circuitry for innate behaviors. Trends Neurosci 29(8): 444-451.

20. Yamamoto D, Koganezawa M (2013) Genes and circuits of courtship behaviour in Drosophila males. Nat Rev Neurosci 14(10): 681-692.

21. Plomin R, Owen MJ, Mcguffin P (1994) The humangenetics of complex basis behaviors. Science 264: 1733-1739.

22. Steyaert J, Fryns JP (2002) Psychiatric genetics: The case of single gene disorders. Eur Child Adolesc Psychiatry 11(5): 201-209.

23. Korenberg JR, Bellugi U, Salandanan LS (2005) Williams syndrome: A neurogenetic model of human behavior. Encycl Life Sci10.

24. Bale TL (2015) Epigenetic and transgenerational reprogramming of brain development. Nat Rev Neurosci 16(6): 332-344.

25. De S, Kassis JA (2017) Passing epigenetic silence to the next generation. Science 356(6333): 28-29.

\section{Your next submission with Juniper Publishers will reach you the below assets}

- Quality Editorial service

- Swift Peer Review

- Reprints availability

- E-prints Service

- Manuscript Podcast for convenient understanding

- Global attainment for your research

- Manuscript accessibility in different formats

(Pdf, E-pub, Full Text, Audio)

- Unceasing customer service

Track the below URL for one-step submission https://juniperpublishers.com/online-submission.php 